\title{
Purchaser-provider: the international dimension
}

\author{
Alastair Mason, Kieran Morgan
}

Purchaser-provider systems in health care are being implemented in several countries and are under consideration in many more. These new arrangements are described for the United Kingdom, Finland, New Zealand, and Australia, and in each case responsibility for funding, purchasing, providing, and ownership is identified. The four systems, along with managed care organisations in the United States, are also compared with regard to several important features. There is a fundamental similarity between these purchaser-provider arrangements but several key differences are well worth systematic study. This is a major challenge for academic bodies in Britain and other countries, and the opportunity to learn from each other should not be missed.

The United Kingdom is not the only country in which purchaser-provider arrangements are being introduced into taxation funded health services. Finland and Sweden have pilot projects under way, and New Zealand and Western and South Australia are implementing major changes. These arrangements undoubtedly have their origins in the commercial sector but they cannot be thought of merely as the introduction of financial transactions between health authorities and so either good or bad for that reason alone. The purchaser-provider separation brings into the open many issues about health care that have previously been obscured. With the identification of purchasers charged with commissioning health care on behalf of a population comes the question of accountability. With the advent of the general practitioner purchaser comes the ethical question of clinical decision making within a fixed budget. Despite similarities in the purchaser-provider arrangements between different countries there are important variations in approach. Study of these variations could, in time, shed light on these questions.

For about two years senior executives from agencies responsible for purchasing in Helsinki, Auckland, Perth, Adelaide, and Bristol have been comparing experiences and sharing expertise. This paper was written after a meeting of this international network in Bristol in March 1994 and describes the different ways in which purchaser-provider arrangements are being implemented internationally.

South Western Regional Health Authority Alastair Mason, regional director of public health

Bristol and District Health Authority, Bristol BS2 8EE Kieran Morgan, director of public health

Correspondence to: Dr Morgan.

BMF 1995;310:231-5

\section{Structure and funding}

The same basic approach is being pursued in the four countries, in that a distinction is being made between funders and purchasers, and public sector providers are being made more independent and having their ownership role clarified.

Funders are responsible for obtaining and allocating funds to purchasers. To differing degrees funders may also lay down specific policies and priorities, monitor purchaser performance, and administer any regulations concerning purchaser-provider relationships.
Purchasers assess health care requirements and identify opportunities for improving health. They set priorities, develop specifications, and contract with providers for the delivery of services. The range of services for which purchasers are responsible and the degree of risk which they might carry vary considerably.

Providers deliver services against contracts or service agreements and are accountable to purchasers for the quality and quantity of service provided. They may be publicly owned, private, or voluntary organisations and the mix differs between countries.

The need to keep public sector providers at arm's length from their traditional funders has led to the development of the ownership role.

Owners are responsible for safeguarding the integrity of the human, financial, and physical assets in public sector providers and for the emerging role of ensuring an appropriate return on government assets.

\section{New Zealand}

Implementation of the New Zealand reforms started in July 1993. Four large purchasers have been set up for the population of 3.3 million. The North Health Regional Authority, which covers Auckland, purchases for a population of $1 \cdot 1$ million, of whom $23 \%$ are Maori or Pacific Islanders. Regional authorities receive their finance from central government (see fig 1) and have a contract with the Department of Health covering agreed health priorities. Funding is allocated on an age adjusted equitable funding formula with a

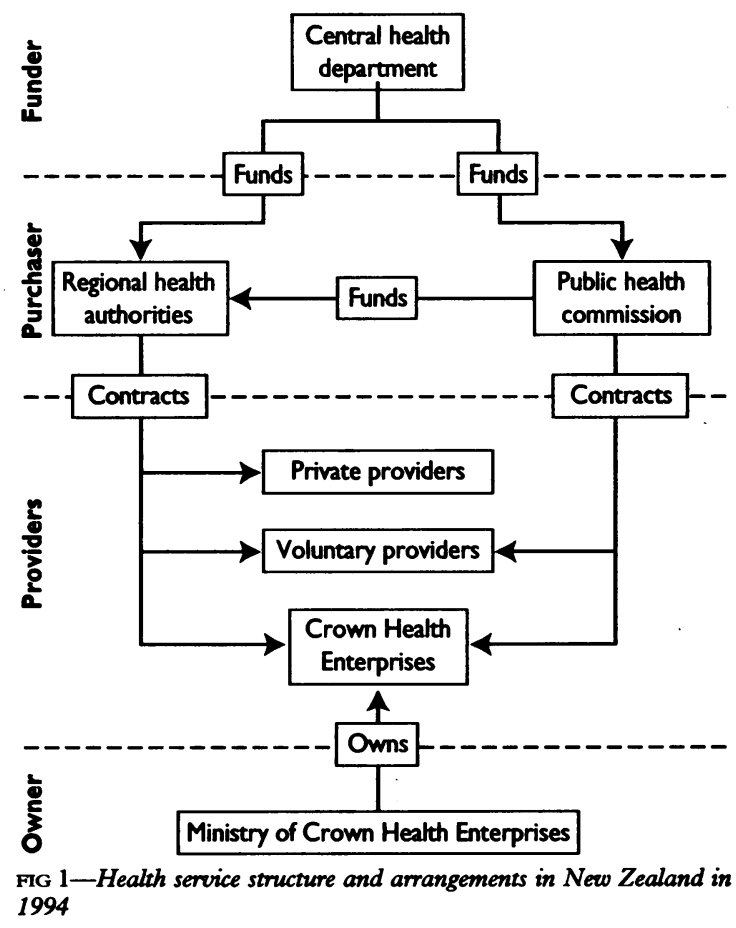


small special needs component for socioeconomic factors. The scope of services to be purchased is extensive, covering all primary, secondary, and tertiary care as well as nursing home care and residential and domiciliary services for elderly and physically disabled people and those with learning difficulties. This comprehensive scope provides an opportunity to switch resources between health and social care according to local need.

In the first year the purchasing of secondary and tertiary health care entailed continuing the historical pattern with mainly public sector providers, which have been transformed into Crown Health Enterprises, owned by the Ministry of Crown Health Enterprises (fig 1). The relationship of the Crown Health Enterprises to a department other than health has strengthened the purchaser-provider split and may help lessen the tendency of purchasers to be protective of local providers.

The development of new providers of primary care is a priority. There are no national restrictions on either the composition or funding of these new agencies. However, with the purchasing of residential and domiciliary services there has been active competition for tenders, and as a result the first year of contracting saw a substantial change in the pattern of services. A nationally based public health commission is responsible for mounting national health promotion campaigns and advising the Minister of Health. It also funds local initiatives, using the regional authorities as its agents to procure the appropriate services.

\section{Finland}

Major work is under way in Finland to introduce a purchaser-provider split in 1995. The Finnish population of about 5 million has a strong network of local government, with around $\mathbf{4 5 0}$ municipalities responsible for a wide range of services including health. The funder of health care is the municipality (see fig 2). Funds are obtained in two ways. The central departments, including that for health, transfer money to municipalities on a population based formula, weighted predominantly according to the wealth of a municipality. Having obtained central funds, each municipality can raise local taxes and then decide how to allocate the totality of funds between the different sectors, such as education and health. There are few nationally determined priorities or programmes.

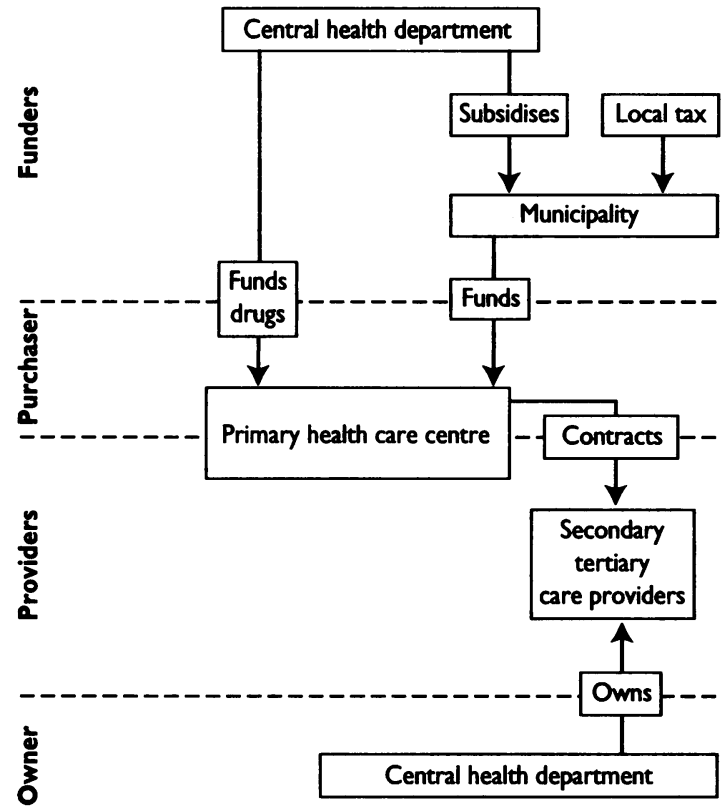

FIG 2-Health service structure and arrangements in Finland by 1995

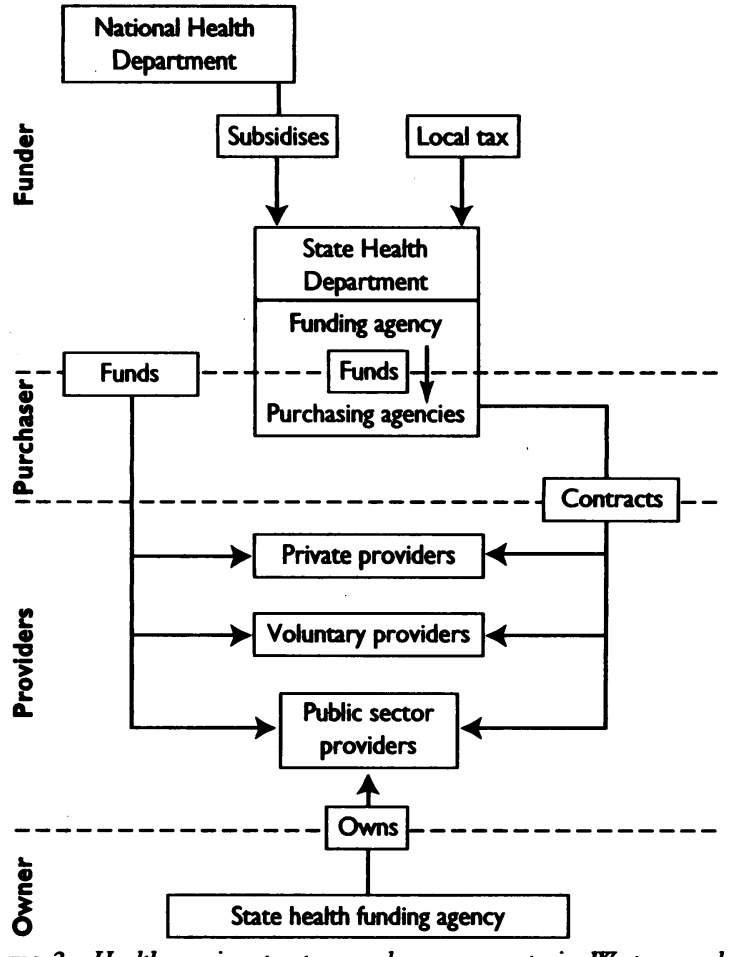

FIG 3-Health service structure and arrangements in Westerm and South Australia by 1995

The purchasers will be primary health care centres, of which there are about 200. Small municipalities share a centre. The primary health care centres, whose doctors are paid on a capitation basis, provide all care outside hospitals and are responsible for purchasing secondary and tertiary care. Major problems are beginning to emerge because of the small size of some of the purchasing groups, particularly when purchasing high cost treatments. The secondary and tertiary care providers are predominantly the $\mathbf{5 0}$ public hospitals. There is only a small private sector. The issue of ownership of the public hospitals in the new system has not yet been fully addressed (fig 2 ).

It is anticipated that in 1995 statements of need will have been completed for about half of Finland and that 60-90 municipalities will have implemented contracting arrangements. An innovative feature of the Finnish reform is a major evaluation study, collecting data both before and after the changes about the use of service for index diagnoses and about the cost and quality of care.

\section{Australia}

Two Australian states are introducing purchaserprovider arrangements. Western Australia started implementation in 1993 and South Australia is preparing for changes in 1995 (see fig 3). Western Australia has a population of 1.6 million in a land mass of 2.5 million square kilometres, three quarters of the population living in and around the capital, Perth. South Australia has a population of 1.4 million in a land mass of about 1 million square kilometres. Seventy per cent of the population live in and around the capital, Adelaide.

Australia has two separate streams for funding health and welfare services. The Commonwealth Health Department dispenses funds for medical and pharmaceutical benefits, nursing homes, and hostel care as well as specific payments for health and disability services. These moneys account for about $30 \%$ of total expenditure on health services. The states are responsible for public hospitals, community health services, mental health, and public health interventions such as immunisation. These funds are sourced 
by the Commonwealth and local taxation. This twin stream funding may militate against the successful introduction of purchasing arrangements and may need to be revised.

In both states the initial change is to review the State Health Departments, which currently incorporate the roles of funder, purchaser, provider, and owner of public providers. In Western Australia legislation to set up autonomous bodies for these functions is not imminent. In South Australia the first step will be to clarify roles and, where feasible, establish separate divisions within the health department. In the first phase of the Western Australia reforms the State Health Department will be restructured to have a funder, the Government Health Service Bureau (which will also act initially as the owner of public sector providers), and a purchaser, the Health Services Contract Bureau. The contract bureau will develop regional purchasers, which may be set up as separate agencies outside the health department (fig 3 ).

In South Australia the process will be similar, though instead of a single purchaser there will be several population based purchasers, initially set up within the current Health Commission. Consideration is being given to replace these with regional boards, funded by a resource allocation formula and purchasing from various health providers.

\section{United Kingdom}

By 1995 the current complex structure in Britain will have been simplified (fig 4). The funder of health care will be the central department, the NHS Executive. Unified purchasing health authorities will be funded on a capitation basis, general practitioner fundholders will receive funds on a basis still to be determined, and NHS trusts will receive capital funds partly on the basis of population and partly according to bed numbers.

Unified health authorities will purchase acute inpatient care, public health interventions, and community health services. They will also fund general practitioners by a mixture of capitation, items of service, and bonus payments. For non-fundholders actual spending on drugs is funded centrally whereas for general practitioner fundholders drugs are part of the cash limited fundholding budget. General practi-

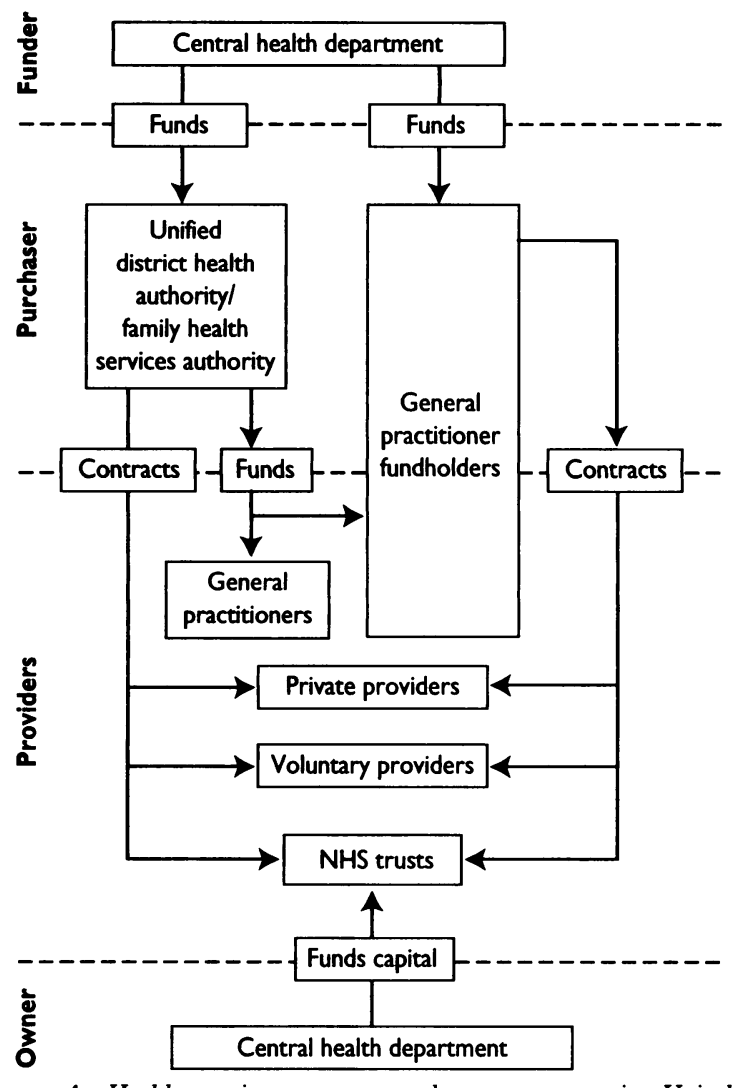

FIG 4-Health service structure and arrangements in United Kingdom by 1995

tioner fundholders purchase in addition a specific range of elective inpatient and outpatient care and community health services and there are firm plans to extend this to cover most aspects of health care for those who wish to participate. The providers are predominantly NHS trusts, which are owned by the central health department (fig 4).

\section{Discussion}

The table lists the different aspects of the arrangements in the four countries and gives the details of managed care systems (such as those found in some

Key features of purchasing and providing in five countries

\begin{tabular}{|c|c|c|c|c|c|c|c|c|c|}
\hline & Purchasing organisation & Board & $\begin{array}{c}\text { Range of } \\
\text { purchaser } \\
\text { responsibility }\end{array}$ & $\begin{array}{l}\text { Separation of } \\
\text { purchaser } \\
\text { and provider }\end{array}$ & $\begin{array}{l}\text { Degree of } \\
\text { central } \\
\text { policy } \\
\text { direction }\end{array}$ & $\begin{array}{c}\text { Contract } \\
\text { mechanism }\end{array}$ & $\begin{array}{c}\text { Resource } \\
\text { context }\end{array}$ & $\begin{array}{c}\text { General } \\
\text { practitioner } \\
\text { purchasers }\end{array}$ & Experience \\
\hline New Zealand & $\begin{array}{l}\text { Separate public authorities } \\
\text { accountable to ministers } \\
\text { (separate minister for } \\
\text { provider organisation) }\end{array}$ & Political appointees & $\begin{array}{l}\text { All health services, } \\
\text { including nursing } \\
\text { home care }\end{array}$ & Near total & Slight & $\begin{array}{l}\text { Contracts are legal, } \\
\text { volume } \\
\text { specifications not } \\
\text { yet sophisticated; } \\
\text { price does not } \\
\text { equal cost }\end{array}$ & No growth & $\begin{array}{l}\text { Planned, most } \\
\text { services }\end{array}$ & Less than one year \\
\hline Australia & $\begin{array}{l}\text { Public authorities accountable } \\
\text { to state and commonwealth } \\
\text { ministers; purchaser- } \\
\text { provider separation by } \\
\text { "Chinese walls" }\end{array}$ & Political appointees & $\begin{array}{l}\text { Most secondary and } \\
\text { tertiary and } \\
\text { community health } \\
\text { services }\end{array}$ & $\begin{array}{l}\text { Planned in two } \\
\text { states }(1995 / 6)\end{array}$ & $\begin{array}{l}\text { Direct guidance, plus } \\
\text { Commonwealth } \\
\text { also purchases in } \\
\text { parallel }\end{array}$ & $\begin{array}{l}\text { Shadow contracts } \\
1994 / 5 ; \text { price } \\
\text { does not equal } \\
\text { cost }\end{array}$ & No growth & $\begin{array}{l}\text { (South Australia) } \\
\text { planned, } \\
\text { (Western } \\
\text { Australia) } \\
\text { most services }\end{array}$ & Not yet \\
\hline Finland & $\begin{array}{l}\text { Separate local authorities (450 } \\
\text { municipalities (5000-40000 } \\
\text { population each) also } \\
\text { purchase civic and welfare } \\
\text { services) }\end{array}$ & Elected & $\begin{array}{l}\text { Most health and } \\
\text { welfare }\end{array}$ & Near total & Slight & $\begin{array}{l}\text { Volume } \\
\text { specifications are } \\
\text { block, and cost } \\
\text { and volume } \\
\text { contracts price } \\
\text { does not equal } \\
\text { cost }\end{array}$ & No growth & Yes, all services & $\begin{array}{l}\text { Gradual } \\
\text { implementation } \\
\text { over next } 14 \\
\text { months }\end{array}$ \\
\hline $\begin{array}{l}\text { United } \\
\text { Kingdom }\end{array}$ & $\begin{array}{l}\text { Separate public authorities } \\
\text { accountable to ministers via } \\
\text { central management } \\
\text { executive, also general } \\
\text { practitioner fundholders }\end{array}$ & $\begin{array}{l}\text { Non-executive } \\
\text { appointees and } \\
\text { executive directors }\end{array}$ & $\begin{array}{l}\text { Most tertiary, all } \\
\text { secondary, some } \\
\text { primary, and all } \\
\text { community (not } \\
\text { "care only" } \\
\text { services) }\end{array}$ & $\begin{array}{l}\text { Different } \\
\text { organisations } \\
\text { closely bound } \\
\text { together }\end{array}$ & Pronounced & $\begin{array}{l}\text { Volume } \\
\text { specifications are } \\
\text { block (mostly, } \\
\text { but some are cost } \\
\text { and volume), not } \\
\text { legal, but quite } \\
\text { sophisticated; } \\
\text { price equals cost }\end{array}$ & $\begin{array}{l}\text { Some } \\
\text { growth }\end{array}$ & $\begin{array}{l}\text { Yes, partial } \\
\text { scheme } \\
\text { (roughly } 30 \% \\
\text { of population } \\
\text { covered) }\end{array}$ & Three years \\
\hline $\begin{array}{l}\text { United States } \\
\text { (managed } \\
\text { care } \\
\text { systems) }\end{array}$ & $\begin{array}{l}\text { Separate commercial } \\
\text { organisations insuring up to } \\
\text { half a million people and } \\
\text { contracting with range of } \\
\text { preferred providers for all } \\
\text { health care }\end{array}$ & $\begin{array}{l}\text { Shareholders in profit } \\
\text { or not for profit } \\
\text { organisations }\end{array}$ & $\begin{array}{l}\text { All health services, } \\
\text { including nursing } \\
\text { home care }\end{array}$ & Total & $\begin{array}{l}\text { None (but fiscal } \\
\text { measures) }\end{array}$ & $\begin{array}{l}\text { Very sophisticated; } \\
\text { legal contracts } \\
\text { price does not } \\
\text { equal cost }\end{array}$ & Growth & $\begin{array}{l}\text { No, but GPs have } \\
\text { financial stake } \\
\text { in purchasing }\end{array}$ & Many years \\
\hline
\end{tabular}


health maintenance organisations) that are funded by insurance and are being developed in the United States. All health services are undergoing change and the comments relate to their status from the first half of 1994 to the same period in 1995.

\section{ORGANISATIONAL ACCOUNTABIITTY}

The separation of purchasers from providers has exposed the issue of accountability. Purchasers must measure up to public expectations when no national economy can afford an unlimited choice of services. Three models of purchasing agencies are emerging. In the United Kingdom, Australia, and New Zealand the purchasers are quangos (quasiautonomous nongovernmental organisations) appointed and funded by central or state governments. In Finland accountability is exercised through local government; funds are raised through central taxation augmented by local taxation, and other civic services compete for these funds. The managed care systems in the United States are commercial organisations with boards of directors accountable to shareholders.

In all five countries the boards of purchasing agencies clarify for the public who is responsible for defects and shortcomings. In the United Kingdom, Australia, and New Zealand boards are composed of political appointees and executive directors of the organisation. In these three models it seems that public pressure is most noticeable in maintaining existing systems rather than supporting the radical changes necessitated by clinical developments and financial reality. It is not clear to what extent these boards encourage or are influenced by public opinion, but in all countries there is great interest in appealing directly to the populations they serve over strategic questions.

\section{RANGE OF PURCHASING RESPONSIBILITY}

The range of purchasing responsibility varies widely among the five countries. The greatest scope for the purchaser is in New Zealand, where the regions purchase all health and social services, including homemaker services, as well as handling disability benefits.

\section{PURCHASER-PROVIDER SEPARATION}

The separation of purchaser from provider seems to be clearer and more complete outside the United Kingdom. In Britain purchasers and providers are bound together in a "managed market," in which each organisation's choice of action is limited by the effect it has on the other.

\section{CENTRAL POLICY DIRECTION}

The degree of central or state influence in the taxation funded services varies from strong in the United Kingdom and Australia to weak in Finland, where the influence of $\mathbf{4 5 0}$ municipalities is paramount.

\section{CONTRACT MECHANISMS}

All the systems use contracts to mediate the relationship between purchasers and providers. They have very different characteristics, varying from legally enforceable and price sensitive in the United States to annual agreements about the scale and nature of services with price equating to cost in the United Kingdom. The nature of contracts has profound implications for the extent to which health care can operate as a market.

One highly visible result of these reforms has been their dependence on information for contract specification and monitoring. All five countries place a high value on getting the right balance between detail and accuracy, on the one hand, and controlling the inevitable rise in transaction cost, on the other. In general, the necessary information systems are in early stages of development in New Zealand, Australia, and Finland. In the United Kingdom they are well advanced. In the United States they are highly sophisticated-necessarily so, as cash transactions are more pertinent.

The simplest type of agreements are block contracts, in which a whole service is purchased at a fixed price over a set time. Block contracts may minimise risk and disruption for purchasers and providers but may militate against strategic changes that either side may wish to promote. They are the predominant form of contract in the United Kingdom (though general practitioner fundholders use other forms) and Finland and possibly reflect the early state of development of the reforms. More complex arrangements, where procedures and individual service volumes are costed and then paid for when they are delivered, are the norm in the United States and are under development in the other four countries.

\section{MATCHING PRICES WITH COST}

In the United Kingdom providers are required to set prices for their services that are the same as their exact cost. Furthermore, they may not cross subsidise services in which income does not cover cost by using excess income from other parts of the organisation. Arguably this feature of the British reforms prevents the operation of a true market in health care: providers have no incentive to promote innovative and perhaps cheaper services that might attract income and strengthen the provider organisation as a whole. By the same argument purchasers also are unlikely to shop around for the best value for money and are locked into contracts with relatively few monopsonist providers.

This purely economic view, however, is not strictly relevant to health care: arguably choice of provider is more to do with clinical relationships than price, which is as it should be. Realistically, few purchasers have more than one or two providers between which they can make a choice in their locality. And patients are not expected to travel far for health care even if it is good value for money, as this would be making a saving to the NHS at the expense of patients and carers.

All the countries in this review except the United Kingdom allow or intend to allow providers to price their services differently from real costs and theoretically to make profits. But experience, even in the United States, suggests that they are unlikely to operate in a truly free market. Whatever the advantages of a market in health care, the strongest force governing access to health care is still the referral of patients from one clinician to another.

Contracts are legally binding in New Zealand and the United States but not in the United Kingdom. The legal status of contracts in Finland and Australia is not yet clear. Ministers in Britain seem anxious to avoid the complexity and cost of legal battles over the fulfilment or otherwise of purchaser-provider service agreements. Such disputes would be little understood by the public and regarded with suspicion. Instead, the NHS Executive presides over a process of arbitration which is evolving with experience rather than being founded on established rules. Countries with legal redress find that firmness in dealings between purchasers and providers is essential if the system is to work and that a legal framework is required. This framework may also be necessary if both sides are to be openly accountable for their actions.

\section{RESOURCE CONTENT}

In all five countries affordability of health care, whether by individuals or national budgets, is a real concern. All the reforms are meant to tackle supply and demand, key features alongside public preference in the issue of affordability. Whether they are effective in 
this aspect or not, we emphasise as background to this review that some real growth is anticipated in the next few years in the United Kingdom and rather more in the United States. Health budgets are not expected to grow in New Zealand, Australia, and Finland.

GENERAL PRACTTTIONER PURCHASING

Direct purchasing by doctors in primary care is a consistent theme in all five countries. A prime objective of the reforms everywhere is to give general practitioners a major role in shaping primary, secondary, and community health care and to counter the perceived dominance of specialists in service development. Budget holding is regarded as an essential part: arguably, only when general practitioners have financial clout can they demand higher standards and better value for their patients. All schemes are voluntary and there is much debate over the ethical propriety of doctors holding cash limited budgets and perhaps having to make clinical decisions in the light of cash flow. As in the United Kingdom, it is this element of the reforms that is proving the most controversial and about which there is most suspicion of government's motives by both the doctors and the public. Nevertheless, the notion that it is reasonable for general practitioners to shoulder some degree of responsibility for the resources their decisions can commit is gaining ground, and it is the detailed nature of the various schemes which allow this to happen that is at issue.

The most radical scheme is developing in Finland, where cash budget holding by general practitioners for all aspects of health care is proposed. This budget will already have been determined in the light of local priorities in health, social services, education, and environmental matters by elected representatives of the municipality. In managed care systems in the United States general practitioners may benefit financially if they practise within a budget for specialist care for their patients. This arrangement is presumably acceptable to the shareholders-they insured themselves. Less complete schemes are evolving in the remaining countries, that in the United Kingdom being regarded by others as an interim solution. A recent NHS initiative on general practitioner led purchasing clarified much of the compromise inherent in the old scheme for general practitioner fundholders by offering a choice to general practitioners about the level of responsibility they wished to accept and by promising guidance on performance management of the scheme by health authorities.

\section{Evaluation}

The purchaser-provider model is clearly established in the United Kingdom and in parts of the health care system in the United States and has diffused to other parts of the world. This spread is mainly to English speaking countries but there are signs that this will not be for long. Reform of health care in this direction is rightly accompanied by much public debate, which tends to be inward looking. Attempts within countries to evaluate the progress of change and to adjust the arrangements accordingly often founder because of the animosity that can accompany comparison between different parts of the same system that have implemented controversial reform at a different pace. This is evident in policymakers' attempts to understand the impact of general practitioner fundholding in the United Kingdom.

Only in Finland has any formal evaluation of the effect of reform on health or health care been instituted. There is now the opportunity to make comparisons between fundamentally similar purchaser-provider systems in several countries that exhibit differences in important aspects of the way they do things. It is time to bring these differences under closer scrutiny and to learn what we can from them. This will represent a major challenge to our academic bodies and policy institutes.

Firstly, they need to agree the common outcome measures that indicate success in any health care system. These will include changes in measures of population health, of cost efficiency in health care, and of public satisfaction. Then they must carefully define the key differences between the systems-some of which have been highlighted in this paper-and follow progress in each country over the next few years. None of this will be easy but we are convinced that the effort will be worth while. A natural experiment is taking place on a global scale and, with much at stake, this is an opportunity not to be missed.

Corporate collaborators in the international network are: Adelaide, South Australia (David Filby); Auckland, New Zealand (Mary Ann Boyd); Bristol, United Kingdom (Kieran Morgan); Helsinki, Finland (Ilka Vohlonen); Perth, Western Australia (Steve Anderson). Personal collaborators are: Bob Evans (Vancouver, Canada); Stephen Lewis (Saskatchewan, Canada); Banks Warden (Seattle, USA); Alastair Mason (Bath, United Kingdom).

(Accepred 14 November 1994)

\section{ANY QUESTIONS}

A 76 year old man has a diagnosis, proved by biopsy, of pemphigus foliaceus, which is reasonably well controlled by azathioprine and minocycline. The occasional flare ups are associated with a history of handling sheep that have been recently dipped. Could there be a connection?

Pemphigus foliaceus is an autoimmune disease in which autoantibodies directed to the intercellular cement in the epidermis activate protease enzymes, which cause acantholysis and the formation of superficial blisters. Several drugs have been described as inducing a pemphigus foliaceus-like eruption, including penicillamine, captopril, rifampicin, penicillin, ampicillin, pyritinol, and piroxicam. ${ }^{1}$

Sheep dips contain organophosphate insecticides to destroy ectoparasites. These drugs are anticholinesterases and work by inhibiting anticholinesterases in the parasites' nervous system. Organophosphates are well absorbed through the skin, and absorption is rapid through the palms despite the thick keratin layer. ${ }^{2}$ Poisoning due to sheep dips is usually symptomatic, with blurring of vision, headache, nausea, sweating, vomiting, and abdominal pains, and is due to poor work practices. Given the exposure that this patient was subjected to, I do not expect that he would develop any of these symptoms.

Sensitisation of the skin after prolonged intermittent contact has been reported, but this would cause an eczematous eruption at the sites of contact, which could result in the formation of tense bullae but not a pemphiguslike syndrome. The organophosphates have no structural similarities to any of the drugs known to induce pemphigus, and pemphigus has never been reported after contact with sheep dips.

It is unlikely that contact with sheep dips causes the observed exacerbations in this patient's pemphigus foliaceus. Possibly a primary irritant dermatosis may aggravate the signs and symptoms of pemphigus foliaceus at contact sites. If that is the case protective gloves and clothing should prevent this from occurring in the future.-A C CHU, consultant dermatologist, London

1 Fellner MJ, Moshell A, Mont MA. Pemphigus vulgaris and drug reactions. Int I Dermatol 1980;20:115-8.

2 Namba Y, Nolte Cr, Nackrel J, Grob D. Poisoning due to organophosphate

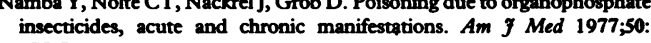
475-7. 